вчення, від його викривлення, від неправедного виконання основних вимог i релігійних обов'язків. Завдяки фудаменталізації якоїсь з релігій виявляються причини кризи суспільства, падіння його моральності, зниження рівня духовності людей, входження людства в економічні і соціальні колапси. Тi, хто поділяв такі думки, тобто прихильники фундаментальних віроповчальних положень, очищали та зміцнювали ортодоксальне ядро всередині вже існуючого віросповідання, а зрештою сприяли конфесійному самозбереженню, оскільки посилання на історичний досвід, вічні цінності, чистоту «віри батьків» більш переконливіші, ніж теперішні вигоди. Ті ж, хто прагнув і добивався змін, творили нові конфесії і нові ідентичності, що свідчило про духовно-релігійний потенціал людства, яке покликано не тільки зберігати, але й розвивати свої духовні світи, представлені в тисячі існуючих і майбутніх традиціях.

\title{
Проф. A.Аpicmoва
}

\section{4. Природа мусульманського фундаменталізму}

До числа суттєвих особливостей оксидентальної ментальності 3 iї тяжінням до раціонально-розбудованого, логіко-центричного знання відносяться й спроби підвести будь-які феномени під чіткі визначення, узагальнення, концепти. Природньо, що одним із аспектів «західного» сприйняття i розуміння ісламу $є$ прагнення виділити й сконцентрувати в одному стислому та водночас ємному визначенні найістотніші риси ісламу, оте «єство мусульманства».

Незайве зазначити, що західне ісламознавство дуже чітко усвідомило той факт, що іслам просто не вписується в межі такого поняття як «релігія» (точніше, в межі того, що вважається релігією в західній духовноінтелектуальній традиції); іслам постав як дещо «понад-релігійне», «понадсвітоглядне», щось тотальне у своєму функціонуванні, «матричне» щодо усіх сфер життя суспільства. Іслам - держава і сім'я, влада і політика, економіка й соціальна організація, освіта і етика, релігія і право. Тож дуже поширеним і в принципі загальновизнаним стає визначення ісламу як «способу життя».

Своєрідність буття і формовиявів ісламу, серед іншого, обумовлює така його іманентна властивість, яку ми попередньо означили як «максималізм». Йдеться про певний спосіб світорозуміння, світосприйняття i світоперебування, який тяжіє до певного максимуму в ідейному і практичному смислах, втілюється у загострене відчуття граничності, межовості в іiі найрізноманітніших виявах: від граничної тотальності й категоричності релігійної свідомості, переконання у завершеності, остаточності і вищості власної істини - до крайньої відданості й безкомпромісності заради 
досягнення покладених цілей, дихотомічності щодо іншого (немусульманського) світу. Підкреслимо, певні максималістські парадигми імпліцитно містяться в кожній релігійній системі вже через саму природу релігійності як такої, але оприсутнюються вони не стільки через віроповчальний, духовний зміст релігії, скільки через специфіку його освоєння на рівні буденної індивідуальної свідомості, з ії когнітивною обмеженістю, неминучим спрощенням i «огрубінням» віровчення, вкоріненими стереотипами, чутливістю до навіювання, схильністю шукати прості й чіткі відповіді на складні запитання. У сполученні із впливом соціальних чинників це призводить до того, що «земне втілення» найдуховніших релігійних настанов нерідко обертається на їх пряму протилежність - насильство, диктат, безжальність, «несвободу совісті».

Можливо, самий термін «максималізм» і не є найбільш вдалим і ємним, проте він позбавлений такої насиченості негативних конотацій, що властива переважній більшості понять, якими європейські ісламознавці звично таврують іслам. Звісно, спроба уникнути низки християноцентричних понять на кшталт «фундаменталізму», «ревайвалізму», «радикалізму», «традиціоналізму» не сильно виправить наукову ситуацію, але дозволить, принаймні, відсторонитися від стереотипових оціночних кліше, спонукає до рефлексії і дискусії щодо адекватності вживаного понятійно-термінологічного апарату. Відтак, спробуємо виділити і узагальнити ті особливості ісламу, щуо фіксуються в понятті «релігійний максималізм».

Почнемо, найперше, 3 того, що духовним стрижнем ісламу є ідея єдиного Бога, абсолютної і безмежно досконалої трансцендентної сили. Разом з тим, при порівнянні з іншими монотеїстичними традиціями, впадає в очі, що для ісламу характерне суворіше, однозначне і беззаперечне, постулювання єдності й одинності Бога, «духовної вертикалі» між Богом і світом, Богом i людиною, яка має абсолютний, «позадоговірний», надприродний i понадлюдський характер. ${ }^{253}$ Ця обставина надає мусульманській духовній традиції та мусульманському менталітетові виразної специфіки - останній стає суцільно релігійним менталітетом, де нероздільне світське і релігійне, сакральне і земне, де кожен об'єкт, явище чи дія співвідноситься з його релігійно заданим смислом, у контексті значень, приписів і норм ісламу. Відтак мусульманин «мислить мовою ісламу», погляд на релігію «з боку» для нього $\epsilon$ просто неможливим (скажімо, ставлення до Корану як до пам'ятки культури, складеної і записаної людьми - неприпустимим і кощунним). Тож будь-які прояви зверхнього, легковажного, гротескного, іронізуючого сприйняття базових ісламських цінностей (чи-то Книги, чи особистості Мухаммеда, культової практики) сприймаються надзвичайно гостро i обурливо.

Для ісламу притаманне відчуття невимірної онтологічної, етичної, гносеологічної дистанції між людиною і потойбічним Богом - настільки

253 Запад и Восток. Традиции и современность. Курс лекций для негуманитарных специальностей. - М., 1993. - С. 162-163. 
нездоланної, що до Бога незастосовні будь-які людські мірила і якості. Таке утвердження абсолютної супрематії і безмежної суверенності Бога набуває гіпертрофовано імперативного характеру стосовно людини, «прочитується» передусім у концептах владності, підпорядкованості, послуху (а не в концептах, скажімо, «любові до Бога», «єднання з Богом», ${ }^{254}$ «угоди з Богом», «сполучення Божественної i людської природи» тощо), довірливого i безсумнівного прийняття Божественного керівництва. За Кораном, стосунки між Богом i людиною будуються на безкінечному милосерді Бога i добровільній покорі й слухняності з боку людини. Неухильне слідування велінням Бога чи пророка, служіння й самозречення заради Творця набуває сенсожиттєвої цінності. Відповідно, вищим ідеалом такого служіння $є$ перетворення цілого світу, зануреного у «відступництво», «язичництво», «невігластво», згідно до настанов Всевишнього. В цьому контексті, акцентуємо деякі витокові інтуїції ісламу.

1) Іслам презентує не просто монотеїстичний світогляд, але світогляд із загостреним відчуттям своєї «довершеності» й «завершеності», «граничності», «остаточності» (останнього пророцтва, місії, Корану), певної «зламності» у стосунках між людством і Богом. Думається, таке самоусвідомлення ісламу як «останньої Божої спроби» навернути людство на істинний шлях, а мусульман як виконавців покладеної на них святої місії - генерувало в духовній атмосфері епохи, безумовно насиченої геополітичними, економічними, класовими інтересами, ще й специфічну духовно-релігійну складову - відчуття особливої відповідальності за реалізацію Божественних настанов, а відтак - i спрямовану на навколишній соціальний світ гіперактивність. Цінність дієвого, усердного, відчайдушного служіння Аллахові стає своєрідною «релігійною оболонкою» пасіонарності мусульман, яка хвилями виплескувалася в ході історичного становлення мусульманської цивілізації. I саме ця особливість завжди заважала компаративістам однозначно віднести мусульманський світ до східного вектору світового розвитку і виділити в ньому «типові характеристики» Сходу (як-от аскетизм, відсторонення від мирського, містичний інтуїтивізм, суб'єктивізм, інертність тощо), натомість примушувала висновувати про близькість ісламської та іудео-зороастрійсько-християнської соціально-економічної та суспільно-політичної етики. В контексті цих духовних традицій, як зазначає Ю. Павленко, «соціальна поведінка особи сприймається як високо значуща i для долі світу, і для майбутнього самої людини, котрій надана свобода вибору між добром і злом». Це передбачає установку на активну, раціонально-вольову позицію людини у ставленні до зовнішнього світу і право людини на перетворення довкілля у власних

254 Звісно, кожна релігія породжує і власну традицію містицизму, яка базується на інакшому духовному досвіді. В ісламському контексті це найвиразніше втілено у вченні і практиці суфізму. Але, в даному разі, ми залишаємо осторонь містичні традиції суфізму з їх надзвичайною своєрідністю. 
iнтересах. ${ }^{255}$ Подібна релігійна, етична та соціальна установка, саме через свій над-ціннісний для людини зміст, здатна втілюватися за певних умов в дії граничного, радикального, екстремістського характеру.

2) На всю історію формування та інституалізації ісламу сильний відбиток учинив його генетичний зв'язок з іудео-християнською традицією, усвідомлення ісламської ідентичності рівним чином як через сполучення, так i через вирізнення з цього монотеїстичного річища. Будучи наймолодшою серед релігій, яким судилося стати світовими, іслам, однак, своєї молодості не усвідомлював, натомість ідентифікував себе із давньою авраамічною традицією, поверненням до витокового монотеїзму, ad fontes, яке заклало архетип буття ісламу взагалі на всі подальші століття його існування. Можна погодитися з висновком, що релігійна самоідентифікація Мухаммеда веде відлік з усвідомлення того факту, що Авраам, не будучи ні іудеєм, ні християнином, був уже віруючим в єдиного Бога, інакше кажучи, з урозуміння того, що $є$ i можлива релігія єдинобожжя «поза десятьма Мойсеєвими заповідями та євангельськими блаженствами». ${ }^{256}$ Відмова іудейських та християнських громад підтримати діяльність Мухаммеда (яку той позиціонував як відродження початкового та істинного однобожжя, зцілення «зламаної гілки Ібрагіма»), сприяла формуванню у мусульман гострого відчуття своєї духовної винятковості, як носіїв істинного й остаточного пророцтва в середовищі заблудлих «людей Книги».

3) Етика ісламу побудована в координатах фаталістичної моделі. I виразна нормативність етичної системи, i сувора регламентованість соціального буття людини в ісламській культурі будуються на уявленнях про цілковиту залежність усього сущого від Абсолюту, який не допускає нічого випадкового, незнаного, хаотичного. Напередвизначеність долі і поведінки людини стверджується численними аятами Корану. Природньо, що від часів перших халіфів і далі протягом усієї історії мусульманства точилися спори щодо меж передзаданості долі i вчинків людини, особистого вибору i персональної відповідальності перед Аллахом, теодицеї тощо. Однак, аксіологеми персоналізму, індивідуалізму, особистої свободи, безумовної цінності особистості та іï буттєвої самостійності не були і не стали ісламськими. Релігійний зміст ісламу невіддільний від віри у тотальну детермінованість життя людей, передвічну заданість їх долі.

4) Особливістю мусульманського віровчення і менталітету стає глибоке переконання в тому, що послане Господом арабському народу через пророка Мухаммеда Одкровення є не просто первісно-істинним і найдосконалішим у своєму словесному втіленні, але останнім і остаточним, яке самим своїм існуванням скасовує усі раніше передані Одкровення. Коран для мусульманської спільноти є головним і безсумнівним джерелом світогляду i світопрактики, компендіумом етичних, релігійних, правових, політичних

${ }^{255}$ Павленко Ю.В. Історія світової цивілізації: Соціокультурний розвиток людства / Юрій Віталійович Павленко. - К., 2001. - С. 286.

${ }^{256}$ Журавский А.В. Ислам. - М. , 2004. - С. 17. 
норм, необхідних і достатніх для регулювання життя громади. Культ Корану набуває в ісламі винятковості й тотальності, а наявність Книги стає критерієм жорсткої диференціації релігій та їх сповідників.

Зазначені особливості раннього ісламу, $з$ імпліцитно властивими їм елементами максималізму, визначили його релігійно-духовне обличчя в усі майбутні віки існування.

По-друге, до вихідних концептів «мусульманської ідеї» належить ідея громади одновірців як надетнічної, наддержавної цілісності, незалежної від конкретних форм державного устрою та розуміння мусульманської ідентичності поза співвіднесенням із конкретною партією, соціальною верствою, етнічною чи конфесійною спільнотою, але у сенсі сакральної приналежності до «спасенної групи», найбільш правильного і вірного шляху, утвердженого «праведними попередниками» громади. Відтак відмітною рисою мусульманського менталітету і суспільно-духовних традицій стає спільнотність, корпоративність. Умма постає як специфічна форма соціальної організації надетнічного, надкультурного, надтериторіального типу, що згуртовує одновірців у єдину релігійну спільноту-об'єкт Божественного плану спасіння. Прототипом iі завжди слугувала початкова мединська громада Мухаммеда, яка й досі лишається для мусульман ідеалом соціальнополітичного об'єднання людей, згуртованих вірою. Тож в ісламі індивід ніби розчинюється в цілому - благочестя окремого індивіда визначається не стільки його персональним духовним подвигом, скільки участю у справах умми, інтегрованістю в життя спільноти; умма як колективний носій святості передбачає всеохопне регулювання соціального й особистого життя на основі шаріату, $\epsilon$ соціальним і правовим гарантом для мусульман, основою їх самоусвідомлення.

Таке загострене відчуття спільнотності, універсальної сполученості мусульман понад інші ідентичнісні розбіжності посилює дію об'єктивних механізмів соціально-групової інтеграції (таких, як груповий фаворитизм, груповий егоїзм, груповий тиск, групова фасилітація, ефект поляризації, ефект емоційної підтримки, а разом з тим і неминуче - певну де-індивідуалізацію та стереотипізацію «групомислення»), стандартизації сприйняття значень i смислів. Тому, з об'єктивної точки зору, феномен умми стає втіленням максималістськи-орієнтованої парадигми на рівні соціуму: власна спільнота сприймається як найкраща $\mathrm{i}$ найцінніша серед інших конфесійних (етноконфесійних, соціорелігійних) спільнот.

По-третє, класичний іслам, який не розрізняє духовне і мирське, став цілокупністю, що рівним чином не відділяла релігійне, політичне, правове етичне, культурне начала тощо. Зауважимо, що специфічною особливістю поширення та інституалізації ісламу, порівняно 3 іншими великими релігійними системами, стала генетична зрощеність процесів духовнорелігійного, ідейного протиборства (зіткнення особистої харизми пророка й проповідуваного ним вчення із панівними традиціями) та практики соціальнополітичного реформування і творення нової правової системи. Мабуть, в 
історії і практиці жодної релігії проблема влади та ії використання не стояла так гостро, як в ісламі. Ні Будда чи Ісус, ані Мойсей чи Заратуштра не цікавилися соціально-політичним реформуванням суспільства як конкретнопрактичним завданням. Мухаммед, на відміну від них, $\epsilon$ пророком, який прагне (чи був вимушений?) займатися політичними питаннями 3 цілком конкретною метою, яка мала i земне, і священне значення - збільшити, згуртувати й упорядкувати спільноту одновірців: спершу - в умовах оборони $\mathrm{i}$ активного протистояння 3 іншовіруючими, потім - виконуючи завдання політичного єднання арабських племен і державотворення, далі - заради розширення території впливу єдиної умми перед лицем Єдиного Бога. Нероздільність духовної і світської влади в особі Мухаммеда породжує специфічну форму мусульманської теократії, яка відтоді стає презентатором належного, правильного способу буття умми в світі. Показово, що після смерті Мухаммеда саме проблема влади стала причиною конфесійного розколу, потягла за собою тимчасову політичну дезінтеграцію, розпад мусульманської громади на ворогуючі етно-релігійно-політичні угрупування, вплинувши на політичну долю всього мусульманського світу.

Зрощеність релігійного, політичного, етико-правового компонентів у мусульманському світогляді втілюється в цілій шерезі надзвичайно міцних ідеологем та посилює як дихотомічність сприйняття світу широким загалом пересічних вірян («віруючий» - «невірний», «моральний» - «аморальний», «відданий» - «віровідступник», «дозволене» - «заборонене»), так і дихотомічність реалізованого на практиці суспільного улаштування (чітка відмінність між правами мусульман і немусульман). Слухняність, відданість, дисциплінованість та інші норми етики взаємовідносин всередині спільноти отримували сенс не тільки моральних заповідей і обов'язків, але й політичних і правових імперативів. Держава в цьому разі постає не тільки як політичний, але й релігійний інститут, вона - носій єдиної релігійної ідеї, виконавець завдання зміцнення і поширення віри. Іслам не визнає розбіжності між релігійною громадою i політичним співтовариством, немає окремого «кесарєва» i «богова», всяка політична участь пов'язана 3 релігійною належністю. Відтак і зміна релігії в ісламському суспільстві - неминуче перетворюється з особистого, на суспільне, правове, громадянське і політичне питання. Завдяки ісламу і через іслам арабський етнос усвідомив себе як геополітичного суб'єкта і водночас отримав ідейну силу, що сприяла розширенню, інтеграції та відносній уніфікації контрольованого ним геополітичного простору. Ідеал державності у вигляді халіфату не втрачає актуальності, бо саме ця форма ідентифікації найбільше відповідає історичним і цивілізаційним засадам мусульманського світу.

Отже, політична і соціальна орієнтованість, притаманна ісламу від його найперших початків, стає невід'ємною частиною його духовного змісту. Як наслідок, те, що сьогодні західний менталітет сприймає як «політизацію релігії», насправді для буття ісламу є органічним і природним, властиво ідентичнісним. 
По-четверте. Одна зі специфічних рис ісламського монотеїзму - це актуалізоване сприйняття Бога - Сдиного, Абсолюта, Творця, Промислителя, Судді, Милосердя, Істини - ще й як Законодавця. Роль права у мусульманській культурі важко переоцінити: воно не тільки визначило унікальні особливості мусульманської культури, а й дотепер є одним із головних захисних механізмів резистентності цієї культури іншокультурним, передовсім західним впливам. Ісламський закон - це компендіум ісламської думки, концентрований вираз мусульманського способу життя; нерідко мусульманські правознавці приймають шаріат як синонім ісламу, його концентровану сутність. Ісламському закону притаманний релігійнототальний характер: 1) як універсальна й заповідана Богом нормативносанкціонуюча система він охоплює всі без винятку сфери життя; 2) релігійні та юридичні норми ісламу мають єдине джерело і схожу структуру, юридичні приписи ісламу по суті не відрізняються від культових, а культові $\epsilon$ невід'ємною сферою правового регулювання. Злиття правових, релігійних та етичних засад в єдину цілокупність - принципово відрізняє іслам від християнства, яке не тільки розділяє етику i право, але й припускає можливість протиріччя, конфлікту між ними (ідея - немислима для ісламу). Оцей домінуючий в ісламі нормативно-регулятивний дух i зміст, його виразна «ортопраксичність», націленість на упорядкування і регулювання життєдіяльності умми, міцна сполученість (навіть, нерозрізненість) релігійних, моральних і правових настанов досі тягне за собою пошук нових термінів для означення специфіки ісламу, на кшталт «етико-права», «номократії», тощо.

По-n'яте. Одним із способів збереження самоідентичності мусульманської цивілізації та іï адаптації до нових історичних, культурних, геополітичних викликів став традиціоналізм. Саме він ставав у більшості випадків релігійно-ідеологічною основою численних суспільно-політичних, політико-релігійних, громадянських рухів, течій, організацій, через які здійснювався соціальний поступ. По теперішній час сунітський традиціоналізм, все частіше позначуваний у науковій літературі автохтонним терміном «салафізм», належить до числа найвпливовіших мусульманських рухів, що визначають «обличчя» ісламського світу. Але наа відміну від іудеохристиянської традиції, традиціоналізм в ісламі постав абсолютно специфічним доктринальним, ідеологічним, політико-правовим явищем.

Феномен традиціоналізму в ісламі полягає в тому, що при загальному визнанні усіма мусульманськими течіями сакруму Корану i прикладу Пророка i водночас за умов відсутності єдиного i всеавторитетного, доктрино-творчого інституційного центру, практика «повернення до традиції» стає: а) поширеною, здійснюваною багатьма духовними лідерами в різних обставинах місця і часу; б) належною і навіть необхідною, як єдиний спосіб знайти правильні і безсумнівні відповіді на актуальні запити часу; в) ідеологічно плюральною, застосовною для обгрунтування i апологетичних, $\mathrm{i}$ реформаторських, і радикальних поглядів, а відтак - i різноманітних форм 
соціально-політичної активності мусульман. Тож термін «традиціоналізм» стосовно сунітського ісламу має радше процесуальний, а не «ортодоксальностатичний» зміст: традиціоналізм набуває рис не стільки явища, скільки процесу, притаманного різним історичним епохам і теренам.

Відсутність єдиного інституту «узаконення» догматів, загальновизнаної богословської школи чи інституції, виключних прерогатив духовенства на тлумачення віровчення, єдиного очільника мусульманської умми чи загальноприйнятих авторитетів - все це в сукупності стає постійним детермінуючим чинником і генератором «ісламського плюралізму».

Таке функціонування традиціоналізму частково пояснює природу сучасного релігійного радикалізму в мусульманському середовищі. Зауважимо, що в науковому загалі зіткнулися дві полярні точки зору 3 приводу нарощення в сучасному світі системних процесів сполучення ісламської (чи квазі-ісламської) ідеології та екстремістської, терористичної практики. Прибічники першої візії певні у тому, що ісламу іманентно притаманні концепти і вчення радикального характеру, історично обумовлені способом життя і менталітетом арабських племен, в середовищі яких i формувався іслам, у всьому комплексі своїх базових релігійних, політичних, правових, сімейних інститутів. Прихильники іншої - вважають, натомість, що кожне угрупування, яке здійснює екстремістські, насильницькі, терористичні акції і позиціонує себе при цьому як ісламське, - насправді таким не $є$, а лише прикривається, маскується «оболонкою» ісламу, маючі на меті цілком певні ідейні, політичні чи фінансові зиски. Тож на порядок денний висувається завдання вберегти «справжній іслам» як миролюбну й гуманну релігію від дискредитації і спотворення. Визнаючи припустимість обох підходів, вважаємо, що причина історичного відтворення в мусульманському світі доктрин радикального характеру полягає, серед іншого, у поліморфності традиціоналізму, який через специфіку свого функціонування слугує грунтом $\mathrm{i}$ для радикально-максималістських інтерпретацій. При цьому, сучасний салафізм трансформується, набуває транснаціональних рис і стає значно складнішим і ширшим суспільнорелігійним явищем, аніж його попередні історичні форми.

По-шосте. Для мусульманської ментальності притаманне, як зазначалося, переконання у нерозривності «духовного» $\mathrm{i}$ «дієвого» компонентів ісламу: для мусульман будь-які абстрактні теоретизування $\mathrm{i}$ доктрини абсолютно позбавлені сенсу, якщо їх не можна перенести у сферу практичної дії, використати для належного спрямування людського життя на ретельне виконання волі Аллаха, прискіпливе слідування Сунні Пророка та принципам, встановленим ісламської громадою. 257 Заявивши про свою глобальну місію і покликання бути прикладом для народів світу, іслам кинув виклик не на рівні теологічних дискурсів та дебатів - його виклик був дієвий, практичний і політичний. Ісламським ідеалом було створити світ, в якому за

${ }^{257}$ Максуд Р. Ислам. - М., 2002. - С. 66. 
мусульманського правління був би покладений край ідоловклонінню та багатобожжю, а всі люди Книги могли б жити в суспільстві, регульованому та захищеному мусульманською владою.

Втім, історична конкретика безжальна: блискавичне поширення ісламу відбувалося початково як політична, територіальна та економічна експансія, а не через рішучий релігійно-культурний вплив, здатний швидко перебороти багатовікові релігійні традиції, що визначали духовне життя цивілізаційного поясу Свразії та Північної Африки. Найперші історичні походи ісламу принесли перемоги, отримані силою меча, а не місіонерства. Очевидно, що витоки такої експансійності слід шукати не в ідейному змісті ісламу (точніше, не тільки в ньому), але і в самому способі функціонування тогочасного арабського суспільства. Його ознаками були: тривала відсутність державності (притому в геоареалі, де інститути держави існували не одне тисячоліття); панування свавілля, сили, кровної ворожнечі у міжплемінних відносинах, безперервна шерега війн, яка тягнеться через всю доісламську історію арабів; культ здобичі як засобу до існування, перетворення грабунку на особливе і гідне «ремесло»; низький статус в соціальній ієрархії осілого способу життя, землеробства; домінування інститутів племінного суспільства - влади родової верхівки, клановості, кровної помсти, звичаєвого права тощо. $^{258}$ Цими обставинами напевне не можна нехтувати, оцінюючи соціокультурні передумови і середовище генезису ісламу, який формується водночас і як духовно-релігійний протест проти існуючих реалій, i як їх «духовна проекція», відображення у релігійній формі пануючих історичних обставин та архетипів етноментальності.

Потреба у розширенні земель та підвладних територій $\epsilon$ цілком закономірною у разі, коли основою існування та відтворення соціальної системи є не стільки продуктивне виробництво, скільки зовнішні матеріальні та фінансові джерела (податки, мита, здобич, захоплені ресурси тощо). I справа тут не в суб'єктивних та упереджених оцінках: історичні факти не лишають жодного сумніву саме в експансійному характері утворення Арабського халіфату. 3 цієї точки зору, релігійне вчення і пророцька місія Мухаммеда могли бути дієвими й ефективними в тих історичних обставинах лише за умови, якщо вони давали можливість такого потрактування, яке б пояснювало, виправдовувало (а відтак і наповнювало ціннісним сенсом), нормувало експансійну практику. Це і знайшло своє втілення у вченні про боротьбу в ім'я Аллаха і «джихад меча». Оговоримо, що ідея «джихаду» настільки важлива концептуальна частина ісламу, що іiі значущість корелюється зі «стовпами віри». Причому, серед усіх аспектів ісламу саме вчення про джихад зазнає найбільш викривлених і хибних інтерпретацій. 3 огляду на це, уточнюємо, що наразі йдеться лише про один із багатьох аспектів джихаду, відомий як «малий» джихад.

\footnotetext{
${ }^{258}$ Див.: Агрономов А.И. Джихад: «священная война» мухамеддан. - М., 2002. - С. 8 9.
} 
В силу наявності різних ідейних шкіл, суперечності письмових джерел, сумнівів у достовірності певних хадисів, важко стверджувати, що взагалі існує загальновизнана «класична доктрина» джихаду. Більшість ранніх тлумачників ісламу зійшлися на думці, що обов'язком кожного мусульманина $\epsilon$ участь у священній боротьбі, яка розглядалася радше як засіб поширення ісламу або як оборонний, превентивний захист від нападу i загрози зовні. Цитати 3 Корану та ісламського Переказу (особливо мединського періоду) свідчать, що священна боротьба - не тільки обов'язкова для кожного мусульманина, але є особливою чеснотою, за яку мусульманин може розраховувати на духовне схвалення Аллахом, прощення гріхів, повагу одновірців і навіть на матеріальну винагороду у вигляді трофеїв. Однак, уже в ранній період поширення ісламу не було єдиної точки зору щодо обов'язковості джихаду для мусульманської громади. Така невизначеність лишається константною: адже в ісламі зрештою відсутні механізм чи інстанція, яка б могла поставити крапку в дискусії відносно богословських тлумачень, або ж запропонувати загальноприйнятне рішення.

Міркуючи про особливості «пророцької релігії», Макс Вебер підкреслював, що прямий зв'язок між завданнями служіння релігії i боротьбою з невір'ям з'являється тільки в ісламі (позаяк ця концепція була відсутня в усіх релігійних вченнях Азії, крім зороастризму, але і там опосередковано). На думку Вебера, попередником i взірцем для Мухаммеда в цьому сенсі було вчення іудаїзму, яке імпліцитно містило ідеологему про те, що священна війна дозволяє «народу Ізраїлю» утвердити серед ворогів свій престиж, вивищитися над усіма, хто відтоді мусив служити Ягве. «Мухаммед, - вказує Вебер, - вивів 3 цього вимогу релігійної війни аж до підкорення невірних політичній владі та економічному пануванню віруючих в Аллаха». ${ }^{259}$ Важко погодитися 3 класиком, що цю вимогу «вивів» саме Мухаммед і що подібна ідея від початку мала характер «вимоги», але практика помухаммедових часів засвідчила, що панування над «невірними» вимагало не стільки їхнього навернення в іслам, скільки політичного підкорення народів, що сповідують чужі релігії, та обкладання їх податками, забезпечення ісламу та мусульманам найвищого суспільного престижу.

Досягши домінуючого суспільного статусу, іслам, утім, століттями демонстрував досить високу міру толерантності (в кожному разі, незрівнянно вищу за ту, на яку спромоглося в аналогічні історичні часи християнство). Разом 3 тим, саме в ранньому ісламі формується специфічна концепція спасіння, в якій синкретично сполучені обіцянка світового панування і мусульманського раю, нагороди за участь у війні проти невірних і надії на звільнення від гноблення і страждань. Ті елементи раннього ісламу, які надавали йому характер етичної релігії

259 Вебер Макс. Социология религии. (Типы религиозных сообществ) / Макс Вебер. Избранное. Образ общества. - М., 1994. - С. 143. 
спасіння, у масовій свідомості відсувалися на маргінеси, доки іслам лишався релігією спільноти, втягнутої у військові дії. Поряд 3 цим, виникала і своєрідна «теодицея смерті», що поширювалася на членів умми, релігійного братства - ставлення до смерті на війні, як до сповненої смислу священної дії, своєрідного способу наблизитися до Бога. Цінність життя відтак доповнилася і цінністю смерті. Усі ці виплавлені в горнилі ісламу концепти ставали запотребованими кожен раз, коли внутрішні чи зовнішні конфлікти спонукали до активних соціальних дій широкі маси мусульманства.

Відтак, ідеологема поширення ісламу як релігійного обов'язку і місії умми та ісламської держави ставала інспірацією на суспільно-релігійну активність. Звісно, що ця, священна за своїм походженням, спонука на практиці нерідко вела й веде до наслідків, далеких від духовного змісту ісламу. Визнаємо, множинність інтерпретацій робить джихад дуже зручною концепцією мобілізації суспільства (і маніпуляції ним), тим паче, що через ємність потрактувань це поняття може бути поширена на будь-які дії або засоби. Ідея джихаду, отже, стала джерелом комплексної філософії діï, здатної продукувати світоглядні максими і потужні спонукальні мотиви, придатні для інструментального використання в політичних цілях (при потребі на цьому ідейному грунті можна зростити все - i концепцію захисту ісламу від політичної та ідеологічної агресії Заходу, і концепцію рятування світу, і концепцію відродження «чистоти ісламу» часів Пророка та мединської умми, і концепцію військово-політичної стратегії і тактики в сучасних умовах, $\mathrm{i} . .$.$) .$

Слід зазначити, що західні політологи майже одностайно констатують неможливість цілком і повністю вписати систему поглядів ісламу, найперше з питань війни і миру, в сучасну демократичну модель міжнародних відносин. Така неможливість, з одного боку, пояснюється неуніверсальним характером західних взірців, під які в принципі не можна підігнати усе розмаїття соціокультурних традицій людства. Але, з іншого разючою відмінністю між істинами, проголошеними у священних для ісламу джерелах, і щоденною реалізацією цих істин у політичній практиці.

На наш погляд, зазначені особливості, які в цілісній єдності відбивають унікальність ісламу в царині релігійного досвіду людства, разом $з$ тим, $є$ втіленням релігійно-максималістської парадигми, здатної постійно детермінувати радикалізацію свідомості та діяльності широких соціальних груп. 